\title{
Emergency management in bacterial meningitis and sepsis: application of real time-polymerase chain reaction and FilmArray technology performed directly on cerebrospinal fluid and blood samples
}

\author{
Loria Bianchi, Zaleida Napoli, Swan Donati, Patrizia Lencioni, Fabiano Santoni, Riccardo Lari \\ Analysis Laboratory, S. Jacopo Hospital, ASL3 Pistoia, Italy
}

\section{Summary}

Background and Aims. Bacterial meningitis and sepsis are medical emergencies where tests with a high sensitivity and short turn around time (TAT) are crucial for an early targeted therapy. Aim of this study was the evaluation of an optimal diagnostic strategy for infectious meningitis/sepsis management, assessing seven methods: cerebrospinal fluid (CSF) physical-chemical examination, CSF cultural tests (CCT), Gram stained smears (GSS), CSF latex agglutination test (CLAT), blood culture (BC), Real-Time (RT)-PCR and FilmArray Technology (FAT) performed directly on CSF/blood.

Materials and Methods. Samples of CSF (240), blood (180) and cavitary fluids (9) were tested by commercial RT-PCR (Eurospital and Liferiver kits) and traditional methods. Positive samples (BC and RT-PCR) were tested by FAT (Blood Culture Identification Panel, Biofire, Salt Lake City, UT, USA) performed directly on CSF, blood and cavitary fluids.

Results. In CSF, GSS, CLAT, CCT, RT-PCR and FAT sensitivity was $41 \%, 35 \%, 41 \%, 100 \%$ and $62,5 \%$, respectively. In blood, BC, RT-PCR and FAT sensitivity was $96 \%, 70 \%$ and $44 \%$, respectively. TAT was $48-96$ hrs, $3 \mathrm{hrs}$ and $1 \mathrm{hr}$ and NPV was $98 \%, 89 \%$ and 57\%, respectively.

Correspondence: Loria Bianchi, U.0. Laboratory Analysis, Microbiology Section, "S. Jacopo" Hospital, ASL3, Via Ciliegiole 97, 51100 Pistoia, Italy. Tel.: +39.0573.351925.

E-mail: l.bianchi@usl3.toscana.it

Key words: Real-time PCR; FilmArray Technology; bacterial meningitis; bacterial sepsis; diagnostic algorithm.

Contributions: LB, ZN, RL, study concept and design; LB, PL, FS, acquisition of data; LB, ZN, SD, analysis and interpretation of data; LB, ZN, SD, PL, drafting of manuscript; LB, ZN, FS, RL, critical revision; all authors, final approval of the version to be published.

Conflict of interest: the authors declare no potential conflict of interest.

Received for publication: 4 February 2015.

Accepted for publication: 29 May 2015.

(C) Copyright L. Bianchi et al., 2015

Licensee PAGEPress, Italy

Microbiologia Medica 2015; 30:5084

doi: $10.4081 / \mathrm{mm} .2015 .5084$

This article is distributed under the terms of the Creative Commons Attribution Noncommercial License (by-nc 3.0) which permits any noncommercial use, distribution, and reproduction in any medium, provided the original author(s) and source are credited.
Conclusions. For sepsis management, RT-PCR is faster than BC (3 hrs vs 24-72 hrs), but limited by a low overall sensitivity (70\%), due to the low number of detectable pathogens; FAT, performed directly on positive BC should replace biochemical identification (Vitek 2, Biomérieux Marcy-l'Étoile, France) reducing TAT (1 hr vs 12 hrs). For meningitis management, RT-PCR is the most sensitive and rapid method used in routine and emergency regimen. It is cost effective and it represents the gold standard for diagnosis and follow-up of patients under treatment. For meningitis management, FAT, with a higher sensitivity and rapidity and an easier and objective interpretation, should replace CLAT and GSS in emergency regimen.

\section{Introduction}

Bacterial meningitis is a serious disease with high morbidity and mortality (5). Over 1.2 million cases of bacterial meningitis are estimated to occur worldwide each year (66) causing about 171,000 deaths. Moreover, acute bacterial meningitis is one of the most severe infectious diseases causing neurological sequelae (14). Rapid and correct diagnosis and treatment are critical to reducedeath or permanent neurological damages (such as hearing loss, mental retardation, seizures and behavioural changes) as much as possible $(48,58)$. In patients with suspected bacterial meningitis empirical therapy, based on patient's age, risk factors and clinical features, should not be delayed for more than one hour, while waiting for diagnostic tests results $(34,58)$. Observational studies showed that delaying appropriate treatment of only $2 / 6$ hours is associated with adverse prognosis $(34,42)$.

Practice a small number of them is known to cause over $90 \%$ of meningitis cases. In healthy children and adults meningococcus and pneumococcus alone are responsible for $75 \%$ of cases of meningitis/sepsis and only 3 (Neisseria meningitidis, Streptococcus pneumoniae, Haemophilus influenzae) are responsible for more than $80 \%$ of cases. In breastfeeding babies, the germs responsible for $90 \%$ of meningitis include Streptococcus agalactiae, Escherichia coli, L. monocytogenes and Klebsiella pneumoniae $(11,28)$.

Lumbar puncture is a key diagnostic procedure where an increased cell count in cerebrospinal fluid (CSF) and low CSF-blood glucose ratio are important signs of bacterial meningitis (53). CSF samples should be still warm at arrival and should be examined immediately, within 1 hour. Tests that should be performed on CSF $(11,54,64)$ in emergency regimen, recommended by guidelines, are: a) CSF physical-chemical examination (CPCE), key test for meningitis diagnosis, including: cells count and differentiation, total proteins, CSF-blood glucose ratio and electrolytes (sodium, potassium, chloride). Although no single measure provides a definite diagnosis, a combination of abnormal CSF findings is highly suggestive of meningitis and helpful in determining 
the likely aetiology (5) and directing towards additional investigations; b) Gram stained smear (GSS); c) CSF latex agglutination test (CLAT) for antigen detection ( $N$. meningitidis, $H$. influenzae type b, S. pneumoniae, E. coli, Streptococcus group B); d) CSF cultural test (CCT) for pathogen identification and antimicrobial susceptibility testing; e) additional investigations: serological and Real Time (RT)-PCR tests (58). However, this approach may have some disadvantages in terms of the required rapidity and sensitivity.

Characteristic CSF findings for bacterial meningitis consist of polymorphonuclear pleocytosis $(\geq 100 / \mu \mathrm{L})$, hypoglycorrhachia and raised CSF protein levels $(21,53)$. A cut-off value of 321 leukocytes/ $\mu \mathrm{L}$ showed the best combination of sensitivity (80.6\%) and specificity (81.4\%) for diagnosis of bacterial meningitis (2). However, low CSF leukocytes count can occur, especially in patients with septic shock and systemic complications (61); also paediatric cases of bacterial meningitis without initial CSF findings have been reported (41). On the other hand, cases of bacterial meningitis without initial CSF pleocytosis in adults have rarely been reported (56).

Aerobic culturing techniques are obligatory for community-acquired bacterial meningitis. Anaerobic culture may be important for post-neurosurgical meningitis or for the investigation of CSF shunt meningitis (11). Results of CCT may only be available after 24 to 48 hours and sometimes, when the number of viable organism in the CSF is low, it may take even longer (72 hrs). Moreover, the sensitivity of microscopic examination and CCT can be debated. Bacterial concentration in CSF is a limiting factor for the results of microscopy. Regardless of the type of organism present in CSF, the percentage of positive microscopic results is only $25 \%$ with $<10^{3} \mathrm{CFU} / \mathrm{mL}, 60 \%$ in the range of $10^{3}$ to $10^{5}$ $\mathrm{CFU} / \mathrm{mL}$ and $98 \%$ with $>10^{6} \mathrm{CFU} / \mathrm{mL}(51,65)$.

CCT shows a sensitivity of $61-66 \%$, when CSF collection is performed before the initiation of the therapy (5). Initiation of antimicrobial therapy before lumbar puncture decreases the performance of CCT, the likelihood to detect a low CSF glucose level, and to detect a high CSF protein level; in this case sensitivity of CPCE and GSS in combination is lower than $50 \%$ (13).

An extensive study over a period of 27 years showed that CCT might miss the diagnosis of bacterial meningitis in at least $13 \%$ of cases (58). Acknowledged reasons for this lack of sensitivity are: CSF obtained after starting antibiotic treatment and meningitis due to fastidious or slow growing microorganism (66). For these reasons, CCT remains the gold standard for the diagnosis of bacterial meningitis only for antimicrobial susceptibility testing useful for therapy; however, in emergency regimen molecular tests are necessary to increase sensitivity and reduce Turn Around Time (TAT).

In contrast, CLAT is a rapid diagnostic test for bacterial meningitis, providing results in less than 15 min (58), although its sensitivity and specificity are very low (11). A study of meningococcal meningitis patients showed a strong decline in the sensitivity of CLAT, from $60 \%$ for patients without antibiotic pretreatment prior to lumbar puncture, to $9 \%$ for antibiotic-pretreated patients (11).

Several molecular tests are applicable to meningoencephalitis management, in routine regimen, as additional investigation tests, and in emergency regimen.

Since the 2000s, PCR-based assays has been available to provide an early and accurate diagnosis of bacterial meningitis $(30,51,52,60)$ and many of these are also applicable to sepsis management. Indeed, pathogens as $N$. meningitidis, $H$. influenzae and $S$. pneumoniae are human commensal bacteria that can also cause a spectrum of invasive diseases that include not only meningitis but also pneumonia and sepsis (19).

Some of these assays aim to specific pathogens of bacterial meningitis, such as $N$. meningitidis, $S$. pneumoniae and $H$. influenzae, up to a maximum of 8 pathogens $(16,18,30,65)$, whereas others use broadrange bacterial PCR $(23,35,38,48,51,63)$. The use of broad-range bacterial PCR has the great advantage to detect microorganisms that are less frequently found or even unknown causative agents of bacterial meningitis. Even though broad-range PCR has been available since the early 1990s, most clinical laboratories have not yet implemented this technique in their daily clinical practice because its use is hampered by two major problems. Firstly, this method is more vulnerable to contaminations than a species-specific PCR. Taq DNA polymerase is frequently reported as a major source of contaminating bacterial DNA. Secondly, at this time no DNA extraction protocol with optimal yield for both Gram-positive and Gram negative bacteria is available.

Sepsis represents another microbiological emergency. It is one of the most common causes of death in hospitalized patients with a mortality rate ranging from 28.3 to $41.1 \%$ in North America and Europe (9). From an economic standpoint, sepsis represents huge expenses for the health system, both for the long term hospitalization and the high mortality rates (31): direct costs of sepsis in the United States are estimated approximately 17 billion US Dollars per year, which represent only $30 \%$ of the total cost of the disease if the social costs are also considered. Mortality rate is directly associated with inappropriate treatment: a delayed antibiotic administration causes, on average, a 7.6\% increase in mortality per hour (22). Therefore, it is important the implementation of protocols that allow rapid identification of the infectious agent leading to treatment optimization.

Blood culture (BC) is still considered the gold standard for detection and identification of bloodstream pathogens (36). However, this method presents several limitations (37): a) long TAT (24-72 hrs for positive results, 5-7 days for negative results) that doesn't allow the clinician to take immediate therapeutic decisions with rapid initiation of a targeted therapy; b) low sensitivity, estimated around $20-40 \%$ (50), due to prior antimicrobial therapy, low blood volume and fastidious microorganisms infection (such as Bartonella spp, Francisella tularensis, Mycoplasma spp, Nocardia spp, Rickettsia spp, Coxiella burnetii); c) high risk of contamination.

As for meningitis, implementation of molecular tests based on broadrange PCR presents technical problems such as high risk of contamination and variable extractive yield. For sepsis diagnosis, the most widely used molecular test is the LighCycler SeptiFast (Roche Diagnostics, $\mathrm{GmbH}$, Mannheim, Germany), CE/IVD approved. It is a multiplex RT-PCR identifying 25 pathogens responsible for $90 \%$ of sepsis, by amplification of a portion of rRNA genes (a sequence situated between $16 \mathrm{~S}$ and $23 \mathrm{~S}$ for bacteria and between $18 \mathrm{~S}$ and $5.6 \mathrm{~S}$ for fungi); the identification is performed by melting curve analysis (15). Compared to BC, SeptiFast has shown high specificity (92\%) but variable sensitivity, with an average of $75 \%$ (15), even if higher than BC (36).

A critical step of this method is the extractive phase. The nucleic acids isolation in the SeptiFast protocol includes successive steps of mechanical/enzymatic lyses and glass fibre filtration, a mostly hands-on procedure that takes approximately 4 hours. Recently, this test has been implemented by an automated extraction that decreases TAT ( 4 vs $7 \mathrm{hrs}$ ), with higher sensitivity than the $\mathrm{BC}$ test (44). Technical improvements with amplification and detection in a single step (RT-PCR, microarray) led to the development of molecular test for primary matrices (whole blood, CSF). Advantages are the drastic reduction of TAT (1-6 vs 48-72 hrs) and the increase in sensitivity, due to the ability to detect pathogens during empirical therapy and fastidious organisms (16).

For meningoencephalitis management, many RT-PCR tests are performed directly on CSF samples $(16,30,65)$; these tests are sensitive, rapid and effective being able to detect up to 8 pathogens responsible for $96 \%$ of meningitis. Reported RT-PCR limit of detection (LOD) is $10^{2}$ $10^{4} \mathrm{CFU} / \mathrm{mL}$ in CSF $(59,60)$ and $10^{2}-10^{6} \mathrm{CFU} / \mathrm{mL}$ in blood, depending on the aetiological agent; in particular, Staphylococcus aureus shows one of the highest LOD (25). In sepsis the number of etiological agents is wider and extractive yield from blood is more difficult to standardize; so many molecular tests (Fluorescent in situ Hybridization, FISH; PCR; microarray; mass spectrometry) are focused on rapid pathogen identi- 
fication not directly on blood, but on positive BC (TAT requires at least $24 \mathrm{hrs}$ ). Analytical performance of MALDI-TOF (Matrix-Assisted Laser Desorption Ionization - Time Of Flight) mass spectrometry has been widely studied and high concordance with biochemical identification (>80\%) has been established (36). However, this method has some limitations, a bad performance in identifying fungi (20), the requirement of a high degree of training for results interpretation, and long TAT due to pathogen's growth in BC (12-48 hrs) and in agar plates (46 hrs) (36).

Another technique, FDA approved, allowing a rapid (1 hr) identification from BC is the FilmArray Technology (FAT, BC Identification Panel, BioFire, Salt Lake City, UT, USA). This method is a closed diagnostic system that combines nucleic acids extraction from positive $\mathrm{BC}$, nested multiplex PCR, and post-PCR DNA melting curve analysis (8). It allows the identification of 27 pathogens and 3 antibiotic resistance determinants (KPC, mecA e vanA/B) with reduced sample manipulation (1-2 min), high specificity (85-100\%) and sensitivity (88-100\%) $(3,8,43)$.

As for meningitis, also for sepsis there are RT-PCR methods, CE-IVD approved, available, such as multiplex PCR and quantitative RT-PCR for pathogen load quantification, not possible with tests based on identification from positive BC. The clinical value of load quantification has not been well established, but several studies based on RT-PCR quantification have shown a significant association between high pathogen load and mortality/severity of disease $(17,26,45,62)$, suggesting the use of this method for the evaluation of sepsis severity and for monitoring therapy effectiveness.

Aims of this study were to evaluate: a) optimal strategies for identification of bacterial pathogens in CSF of patients with suspected infectious meningitis, through the assessment of seven methods, including: i) CPCE (total proteins; CSF-blood glucose ratio; cells count; electrolytes: sodium, potassium, chloride); ii) BC; iii) CCT; iv) GSS examination; v) CLAT for antigen detection; vi) RT-PCR and vii) FAT performed directly on CSF samples. Our purpose was to introduce a diagnostic algorithm based on tests performance (sensitivity, positive and negative predictive value, TAT and complexity); b) the sensitivity and negative predictive value of RT-PCR and FAT (performed directly on blood sample) in sepsis management, comparing this molecular technologies with traditional methods like GSS, BC and biochemical identification with the Vitek 2 instrument (Biomérieux, Marcy-l'Étoile, France).

\section{Materials and Methods}

\section{Cerebrospinal fluid samples for meningoencephalitis diagnosis}

CSF samples (240), collected from patients with clinical suspect of bacterial meningoencephalitis, arrived at the Microbiology Laboratory of San Jacopo Hospital of Pistoia (Italy), during the period between January 2009 and May 2014, from Intensive Care Unit (ICU), General Internal Medicine Division, Emergency Department (ED) and Neurology Unit of ASL3 Hospitals (San Jacopo Hospital of Pistoia and SS Cosma e Damiano of Pescia, Italy). Blood samples (10 mL) were also collected from all patients and inoculated in a BC bottle (BD BACTECTM PLUS, Aerobic, Becton Dicknson, Franklin Lakes, NJ, USA).

Following the emergency protocol, the following tests were performed immediately: i) CPCE (total proteins; CSF-blood glucose ratio; cells count; electrolytes: sodium, potassium, chloride); ii) CLAT with PASTOREX Meningitis kit (BIO-RAD, Italy) for antigens detection of $N$. meningitidis, H. influenzae type b, S. pneumoniae, E. coli, Streptococcus group B; iii) GSS with the automatic instrument Aerospray MICROBIOLOGY GRAM STAINER 7322 (Delcon) and manual bacterioscopic examination; iv) CCT by inoculation of $500 \mu \mathrm{l}$ of CSF in BactAlert SA bottle and incubation for 5 days in BactAlert System (Biomérieux). For positive samples, subculture was performed on the following plates: blood agar, PolyViteX chocolate agar, PolyViteX VCAT3 chocolate agar, Haemophilus chocolate agar (Biomérieux) and CNA blood agar (Kima, Arzergrande Italy). Pathogen identification and antimicrobial susceptibility tests were performed on Vitek 2 instrument (Biomérieux), using a card specific for Gram negative or Gram positive bacteria, depending on bacteria's growth on selective plates and their morphology observed at the bacterioscopic examination.

\section{Blood samples for sepsis diagnosis}

Peripheral blood samples (180), arrived at the Microbiology Laboratory of San Jacopo Hospital of Pistoia during the period between January 2011 and May 2014, from ICU, General Internal Medicine Division, ED and Neurology Unit of ASL3 Hospitals (San Jacopo Hospital of Pistoia and SS Cosma e Damiano of Pescia), were collected in $\mathrm{K}_{3}$ EDTA tubes from patients with clinical suspect of bacterial sepsis. All samples were preserved at $+4^{\circ} \mathrm{C}$ and processed within $4 \mathrm{hrs}$. At the same time for all patients $20-30 \mathrm{~mL}$ of blood were collected in three subsequent sampling and inoculated in $3 \mathrm{BC}$ bottles for aerobe bacteria (BD BACTEC ${ }^{\text {TM }}$ PLUS, Aerobic) and in 3 BC bottles for anaerobic bacteria (BD BACTEC ${ }^{\mathrm{TM}}$ PLUS, Anaerobic).

\section{Cavitary fluid samples}

Four pleural fluids, 4 peritoneal fluids and 1 synovial fluid were collected in a sterile tube, preserved at $+4^{\circ} \mathrm{C}$ and processed within $4 \mathrm{hrs}$. At the same time $5-10 \mathrm{~mL}$ of the collected fluid were inoculated in a $\mathrm{BC}$ bottle for aerobic bacteria (BD BACTEC ${ }^{\mathrm{TM}}$ PLUS, Aerobic) and in a BC bottle for anaerobic bacteria (BD BACTEC ${ }^{\mathrm{TM}}$ PLUS, Anaerobic).

\section{Pathogen identification and antimicrobial susceptibili- ty test from positive blood cultures}

Incubation of BC bottles and detection of bacteria's growth were carried out for 5 days on $\mathrm{BD}$ Bactec $^{\mathrm{TM}} \mathrm{Fx}$ detection system (Becton Dickinson). For positive BCs, a bacterioscopic examination of GSS, prepared with the automatic instrument Aerospray MICROBIOLOGY GRAM STAINER 7322 (Delcon), was performed. Positive BCs were inoculated on the following plates: blood agar, PolyViteX chocolate agar, PolyViteX VCAT3 chocolate agar (Biomérieux), CNA blood agar, MacConkey agar and Mannitol Salt agar (Kima). Pathogen identification and antimicrobial susceptibility test were performed on Vitek 2 instrument as described above.

\section{DNA extraction}

All DNA samples were extracted with EZ1 Virus Mini Kit version 2.0 (Qiagen, Hilden, Germany) on EZ1 Advanced instrument (Qiagen). Volume of primary sample used for extraction was: $200 \mu \mathrm{L}$ for blood samples, $400 \mu \mathrm{L}$ for CSF and $200 \mu \mathrm{L}$, with $200 \mu \mathrm{L}$ of ATL lyses buffer (Qiagen) for cavitary fluids. Extracted DNA was eluted in $90 \mu \mathrm{L}$, analysed immediately after extraction and stored at $-20^{\circ} \mathrm{C}$.

\section{Real time polymerase chain reaction}

Extracted DNA was analysed with: a) qualitative RT-PCR, using EusepScreen kit and EusepScreen Lattanti kit (Eurospital, Trieste, Italy); b) quantitative RT-PCR, using Liferiver's kit for detection and quantification of $S$. aureus, $S$. agalactiae, Streptococcus pyogenes, $H$. influenzae, $N$. meningitidis, Pseudomonas aeruginosa, $K$. pneumoniae e Legionella pneumophila (Shanghai ZJ Bi, DID). RT-PCR assays were performed following manual's instructions and using Rotor-Gene 6000 or Rotor-Gene Q instruments (Qiagen). Pathogens detectable by the used kits are listed in Table 1. 


\section{FilmArray technology}

All primary samples of blood, CSF and cavitary fluids, resulted positive with RT-PCR and/or BC, and 40 blood samples, resulted negative with RTPCR and BC, were stored at $-20^{\circ} \mathrm{C}$ and later analysed with FAT through offlabel use of the BC Identification Panel kit (Biofire, Biomérieux). The test was performed by adding directly $100 \mu \mathrm{L}$ of blood/cavitary fluid diluted 1:3 with sterile water (DNAse/RNAse free) or $300 \mu \mathrm{L}$ of CSF to Sample Buffer and then following the manufacturer's instruction (8).

\section{Results}

\section{Rapid diagnosis of meningoencephalitis: comparison between traditional and molecular methods}

Table 2 shows pathogens detected in CSF and blood samples analysed for suspected bacterial meningoencephalitis using tradition- al and molecular methods, together with related sensitivity and negative predictive value (NPV). With RT-PCR assay 13\% (32 samples) of total CSF samples analysed were positive: among these, 13 cases resulted positive at bacterioscopic examination and 7 cases (on 20 detectable cases) were positive with CLAT performed in emergency regimen. All bacterioscopic/CLAT positive samples have been confirmed when analysed with FAT, showing an overall sensitivity of 62.5\% (20 total positive cases). The 12 RT-PCR positive/TFA negative samples showed in RT-PCR a Cycle threshold $(\mathrm{Ct})>31$ and resulted negative with all the other used methods, with the exception of a sample that resulted Gram positive at the bacterioscopic examination and positive to L. monocytogenes with RT-PCR; the detected pathogen was then confirmed with biochemical identification of the associated positive BC. All negative results with RT-PCR assay were confirmed with all traditional methods used.

RT-PCR resulted the most sensitive method (100\%), with a NPV of 100\%; FAT, performed by injecting directly the CSF sample (TAT: 1 hour), showed a greater sensitivity than methods traditionally used in

Table 1. Pathogens detected by molecular methods: qualitative Real-Time PCR, quantitative Real-Time PCR and FilmArray Technology Blood Culture Identification Panel.

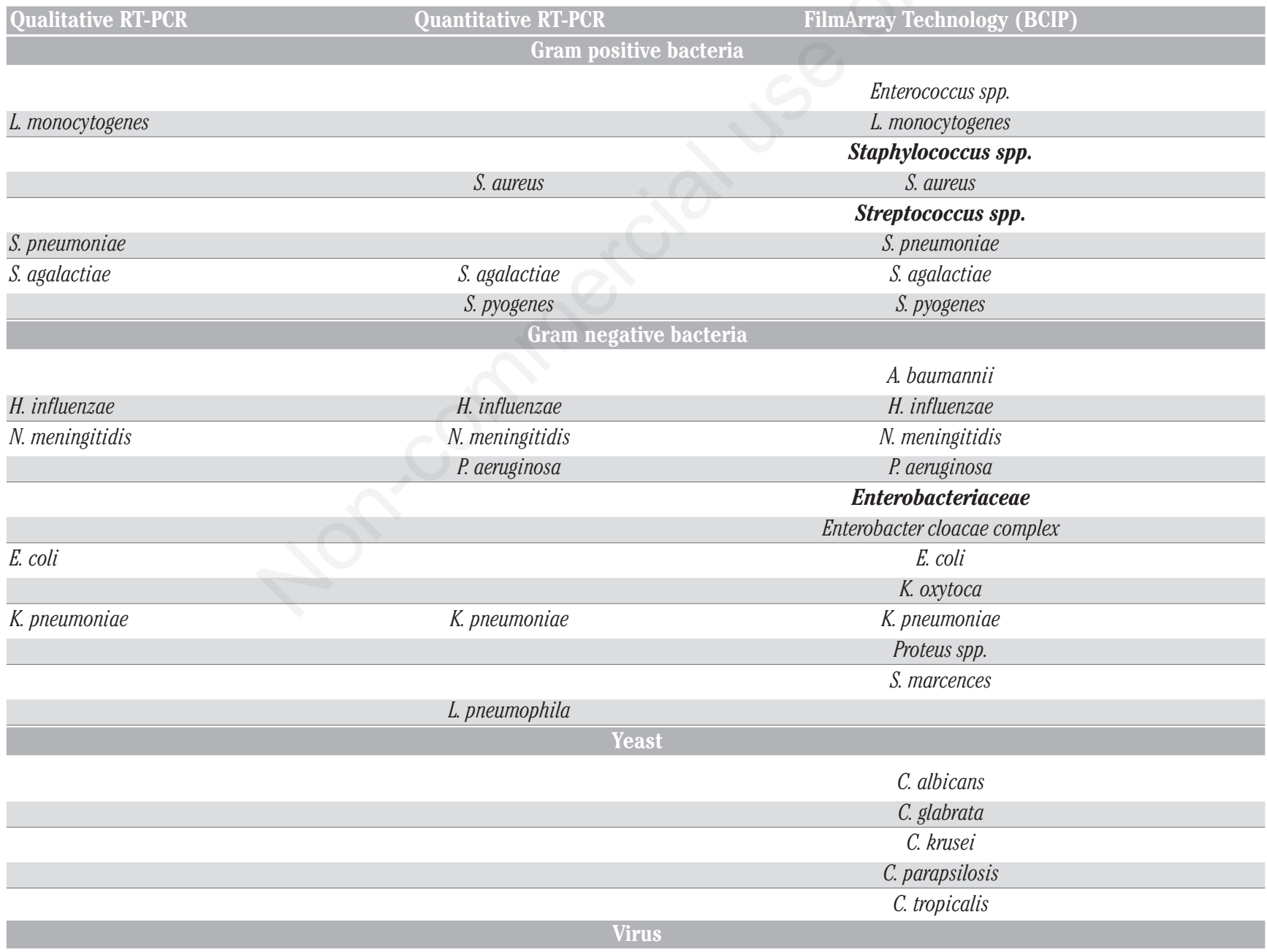


emergency regimen ( $62.5 \%$ vs $35 \%$ of CLAT and $41 \%$ of GSS) and cultural methods ( $41 \%$ of sensitivity for CCT and $47 \%$ for BC).

Table 3 shows results of cells count at CPCE. Only 10 CSF were cloudy/turbid and had high pleocytosis ( $>300$ cells/ $\mu \mathrm{L}$ ): 8 cases had polymorphonuclear cells (PMNC) predominance (70\%) and were positive for bacterial pathogens; 4 of them had adverse outcome (1 patient RT-PCR positive for $E$. coli with $\mathrm{Ct}=29 ; 2$ positive for $S$. pneumoniae with $\mathrm{Ct} \leq 15$ and 1 positive for $L$. monocytogenes with $\mathrm{Ct}=13$ ). The other two patients with high pleocytosis, without PMNC predominance, resulted in one patient positive with RT-PCR viral panel for Human Herpes Virus (HHV)-7 and one patient affected by GuillanBarré Syndrome.

230 CSF samples appeared colourless and clear at examination and in $26.5 \%$ of cases (61/230) they were associated with a mild/moderate pleocytosis (10-300 cells/ $\mu \mathrm{L}): 8$ cases showed more than $100 \mathrm{PMNC} / \mathrm{\mu L}$ and all were positive for bacterial pathogens; 22 cases showed less than 100 cells/ $\mu \mathrm{L}$ with a predominance (70\%) of PMNC and 59\% (13/22) resulted infected with bacteria; among 31 cases that showed less than 100 cells $/ \mu \mathrm{L}$ with a predominance $(70 \%)$ of mononuclear cells (MNC) only 2 cases were positive for bacteria. Only in 3/169 CSF with normal cells count $(<10$ cells/ $\mu \mathrm{L})$ infectious agents were detected: 2 cases with viral infection (HHV-6 and Herpes Simplex Virus-1) and 1 case with pneumococcal infection $(\mathrm{Ct}=34)$.

High NPV for bacterial meningitis was associated with pleocytosis (more than 10 cells/ $\mu \mathrm{L}$ ), but CSF cells count showed low positive predictive value (PPV) in case of mild/moderate pleocytosis (38\%), except when $>100 \mathrm{PMNC} / \mu \mathrm{L}$ were present (100\%). All samples with more than $100 \mathrm{PMNC} / \mu \mathrm{L}$ showed a predominance of PMNC (>70\%).

\section{Comparison between blood culture,}

\section{real time-polymerase chain reaction and FilmArray technology for rapid sepsis diagnosis}

In Table 4 are listed the pathogens detected in blood samples analysed for suspected bacterial sepsis, using traditional and molecular tests, with associated sensitivity and NPV. When analysed with RT-PCR $21 \%$ (38 cases) of the 180 total samples resulted positive; among these, 17 cases were confirmed with BC and FAT and 19 only with BC (negative with FAT). However, 2 samples resulted positive for $N$. meningitidis and $S$. pneumoniae with RT-PCR, were not confirmed with the other two methods (Figure 1).

Among the 142 samples RT-PCR negative, 16 cases resulted posi-

Table 2. Results obtained from analysis of 240 CSF samples for suspected bacterial meningitis by RT-PCR, Gram stained smears (GSS), CSF latex agglutination test (CLAT), Blood Culture (BC) and FilmArray Technology BC Identification Panel (FAT-BCIP) performed directly on CSF.

\begin{tabular}{|c|c|c|c|c|c|c|}
\hline RT-PCR & Cases & GSS & CLAT & CCT & $\mathrm{BC}$ & FAT-BCIP \\
\hline $\begin{array}{l}\text { N. meningitidis } \\
\text { Positive samples } \\
\text { Sensitivity }\end{array}$ & $\begin{array}{c}1 \\
2 \\
3 \\
100 \%\end{array}$ & $\begin{array}{c}\mathrm{GN}+ \\
\text { negative } \\
1 \\
33 \%\end{array}$ & $\begin{array}{c}\text { N. meningitidis } \\
\text { negative } \\
1 \\
33 \%\end{array}$ & $\begin{array}{c}\text { N. meningitidis } \\
\text { negative } \\
1 \\
33 \%\end{array}$ & $\begin{array}{c}\text { N. meningitidis } \\
\text { negative } \\
1 \\
33 \%\end{array}$ & $\begin{array}{c}\text { N. meningitidis } \\
\text { negative } \\
1 \\
33 \%\end{array}$ \\
\hline $\begin{array}{l}\text { Positive samples } \\
\text { Sensitivity }\end{array}$ & $\begin{array}{c}4 \\
1 \\
2 \\
7 \\
100 \%\end{array}$ & $\begin{array}{c}\mathrm{GP}+ \\
\mathrm{GP}+ \\
\text { negative } \\
5 \\
71 \%\end{array}$ & $\begin{array}{c}\text { negative } \\
\text { negative } \\
\text { negative } \\
0 \\
\text { not detectable }\end{array}$ & $\begin{array}{l}\text { L. monocytogenes } \\
\text { negative } \\
\text { negative } \\
4 \\
57 \%\end{array}$ & $\begin{array}{l}\text { L. monocytogenes } \\
\text { L. monocytogenes } \\
\text { negative } \\
5 \\
71 \%\end{array}$ & $\begin{array}{l}\text { L. monocytogenes } \\
\text { negative } \\
\text { negative } \\
4 \\
57 \%\end{array}$ \\
\hline $\begin{array}{l}\text { Positive samples } \\
\text { Sensitivity }\end{array}$ & $\begin{array}{c}1 \\
1 \\
1 \\
1 \\
4 \\
100 \%\end{array}$ & $\begin{array}{c}\mathrm{GN}+ \\
\text { negative } \\
\text { negative } \\
\text { negative } \\
1 \\
25 \%\end{array}$ & $\begin{array}{c}\text { negative } \\
\text { negative } \\
\text { negative } \\
\text { negative } \\
0 \\
0 \%\end{array}$ & $\begin{array}{c}\text { E. coli } \\
\text { negative } \\
\text { negative } \\
\text { negative } \\
1 \\
25 \%\end{array}$ & $\begin{array}{c}\text { E. coli } \\
\text { E. coli } \\
\text { negative } \\
\text { negative } \\
2 \\
50 \%\end{array}$ & $\begin{array}{c}\text { E. coli } \\
\text { E. coli } \\
\text { E. coli } \\
\text { negative } \\
3 \\
75 \%\end{array}$ \\
\hline $\begin{array}{l}\text { S. pneumoniae } \\
\text { Positive samples } \\
\text { Sensitivity }\end{array}$ & $\begin{array}{c}5 \\
3 \\
3 \\
11 \\
100 \%\end{array}$ & $\begin{array}{c}\mathrm{GP}+ \\
\text { negative } \\
\text { negative } \\
5 \\
45 \%\end{array}$ & $\begin{array}{c}\text { S. pneumoniae } \\
\text { negative } \\
\text { negative } \\
5 \\
45 \%\end{array}$ & $\begin{array}{c}\text { S. pneumoniae } \\
\text { negative } \\
\text { negative } \\
5 \\
45 \%\end{array}$ & $\begin{array}{c}\text { S. pneumoniae } \\
\text { negative } \\
\text { negative } \\
5 \\
45 \%\end{array}$ & $\begin{array}{c}\text { S. pneumoniae } \\
\text { S. pneumoniae } \\
\text { negative } \\
8 \\
73 \%\end{array}$ \\
\hline $\begin{array}{l}\text { Positive samples } \\
\text { Sensitivity }\end{array}$ & $\begin{array}{c}1 \\
1 \\
1 \\
2 \\
5 \\
100 \%\end{array}$ & $\begin{array}{c}\text { GN+ } \\
\text { negative } \\
\text { negative } \\
\text { negative } \\
1 \\
20 \%\end{array}$ & $\begin{array}{l}\text { H. influenzae } \\
\text { negative } \\
\text { negative } \\
\text { negative } \\
1 \\
20 \%\end{array}$ & $\begin{array}{l}\text { H. influenzae } \\
\text { H. influenzae } \\
\text { negative } \\
\text { negative } \\
2 \\
40 \%\end{array}$ & $\begin{array}{l}\text { H. influenzae } \\
\text { negative } \\
\text { negative } \\
\text { negative } \\
1 \\
20 \%\end{array}$ & $\begin{array}{l}\text { H. influenzae } \\
\text { H. influenzae } \\
\text { H. influenzae } \\
\text { negative } \\
3 \\
60 \%\end{array}$ \\
\hline K. pneumoniae & 1 & negative & $\begin{array}{c}\text { negative } \\
\text { (not detectable) }\end{array}$ & negative & K. pneumoniae & K. pneumoniae \\
\hline S. agalactiae & 1 & negative & $\begin{array}{c}\text { negative } \\
\text { (not detectable) }\end{array}$ & negative & negative & negative \\
\hline Negative & 208 & negative & negative & negative & negative & not tested \\
\hline Total positive samples & 32 & 13 & 7 & 13 & 15 & 20 \\
\hline Sensitivity & $100 \%$ & $41 \%$ & $35 \%$ & $41 \%$ & $47 \%$ & $62,5 \%$ \\
\hline NPV & $100 \%$ & $92 \%$ & $89 \%$ & $92 \%$ & $93 \%$ & - \\
\hline
\end{tabular}


tive with BC: all these samples were positive for pathogens not detectable with RT-PCR assay, except one patient infected with $E$. coli and one patient infected with $K$. pneumoniae, both treated with antimicrobial agents after the $\mathrm{BC}$ collection, both resulting negative with FAT.

Half (7/14 cases, 50\%) of samples shown positive with BC for pathogens not detectable with RT-PCR, were confirmed with FAT; among the other 7 FAT negative samples, 2 were positive for Staphylococcus capitis and Salmonella spp., two pathogens not detectable with FAT.

Overall, 54 samples were found positive with RT-PCR and/or BC and of these 24 were confirmed with FAT performed directly on blood, with a sensitivity of $44 \%$. BC was the most sensitive method (96.3\%) with a NPV of $98.4 \%$. RT-PCR showed an overall sensitivity of 70.4\%, reaching $95 \%$, when considering only the detectable pathogens. FAT showed a
NPV of $57 \%$, probably an underestimated value, due to the low number of negative samples tested (40 out of 94).

Total pathogens detected in blood samples were 56: 48\% (26 cases) were Gram negative bacteria, among which the more frequent were $P$. aeruginosa (7 cases), E. coli (6 cases) and $H$. influenzae (4 cases), while $46 \%$ were Gram positive bacteria, among which the more common were: $S$. pneumoniae, $S$. aureus (8 cases each) and Enterococcus spp. (5 cases). The remaining $6 \%$ of analysed sepsis resulted positive to Candida spp. (3 cases): 2 C. albicans and 1 C. parapsilosis.

\section{Analysis of cavitary fluids}

Table 5 shows the pathogens detected in the cavitary fluids by cultural methods, RT-PCR and FAT. All samples were found positive with RT-

Table 3. Correlation between CSF cells count and bacterial/viral meningitis diagnosis. Positive predictive value (PPV) and negative predictive value (NPV) are calculated for bacterial meningitis.

\begin{tabular}{|c|c|c|c|c|c|c|}
\hline CSF Cells count & Total cases & Bacterial meningitis & Viral meningitis & Negative & PPV, \% & NPV, $\%$ \\
\hline Pleocytosis ( $\geq 10$ cells $/ \mu \mathrm{L}$ ) & 71 & 29 & 20 & 22 & 41 & 99 \\
\hline High pleocytosis ( $>300$ cells/ $\mu \mathrm{L}$ ) & 10 & 8 & 1 & 1 & 80 & 90 \\
\hline$>300 \mathrm{cell} / \mu \mathrm{L}(>70 \%$ PMNC) & 8 & 8 & 0 & 0 & 100 & 90 \\
\hline Mild/moderate pleocytosis (10-300 cells/ $/ \mathrm{L}$ ) & 61 & 23 & 19 & 19 & 38 & 99 \\
\hline$>100 \mathrm{PMNC} / \mu \mathrm{L}$ & 8 & 8 & 0 & 0 & 100 & 93 \\
\hline$<100$ cells/ $\mu \mathrm{L}(70 \%$ PMNC) & 22 & 13 & 4 & 5 & 59 & 95 \\
\hline$<100$ cells/ $\mu \mathrm{L} 70 \% \mathrm{MNC}$ & 31 & 2 & 15 & 14 & 6 & 89 \\
\hline Normal cells $(<10$ cells/ $\mu \mathrm{L})$ & 169 & 1 & 2 & 166 & & \\
\hline Total & 240 & 32 & 22 & 186 & & \\
\hline
\end{tabular}

PMNC, polymorphonuclear cells; MNC, mononuclear cells.

Table 4. Results obtained from analysis of 180 blood samples for suspected bacterial sepsis by RT-PCR, BC and FilmArray Technology - Blood Culture Identification Panel (FAT-BCIP) performed directly on blood.

\begin{tabular}{|c|c|c|c|c|c|c|}
\hline \multirow{2}{*}{ Pathogen } & \multicolumn{2}{|l|}{ BC } & \multicolumn{2}{|c|}{ RT-PCR } & \multicolumn{2}{|c|}{ FAT-BCIP } \\
\hline & Positive samples & Sensitivity, \% & Positive samples & Sensitivity, \% & Positive samples & Sensitivity, \% \\
\hline N. meningitidis & 1 & 50 & 2 & 100 & 1 & 50 \\
\hline S. pneumoniae & 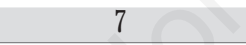 & 87.5 & 8 & 100 & 3 & 37.5 \\
\hline H. influenzae & 4 & 100 & 4 & 100 & 1 & 25 \\
\hline E. coli & 6 & 100 & 5 & 83.33 & 2 & 33.33 \\
\hline K. pneumoniae & 2 & 100 & 1 & 50 & 1 & 50 \\
\hline S. agalactiae & 3 & 100 & 3 & 100 & 1 & $33 ., 33$ \\
\hline C. albicans & 2 & 100 & - & - & 2 & 100 \\
\hline C. parapsilosis & 1 & 100 & - & - & 1 & 100 \\
\hline Enterococcus spp. & 5 & 100 & - & - & 2 & 40 \\
\hline S. aureus & 8 & 100 & 8 & 100 & 4 & 50 \\
\hline S. marcescens & 1 & 100 & - & - & 0 & 0 \\
\hline P. aeruginosa & 7 & 100 & 7 & 100 & 4 & 57.14 \\
\hline A. baumannii & 1 & 100 & - & - & 1 & 100 \\
\hline S. capitis & 1 & 100 & - & - & - & - \\
\hline P. mirabilis & 2 & 100 & - & - & 1 & 50 \\
\hline Salmonella spp. & 1 & 10 & - & - & - & - \\
\hline Positive samples & 52 & 96.30 & 38 & 70.37 & 24 & 44.44 \\
\hline Detectable pathogens & 54 & 96.30 & 40 & 95.00 & 52 & 46.15 \\
\hline NPV & 98.440 & & 88.73 & & 57.14 & \\
\hline
\end{tabular}

$\mathrm{BC}$, blood culture; NPV, negative predictive value. 
PCR (100\% of sensitivity), while 2 pleural fluids, one positive for $S$. pneumoniae and one for $H$. influenzae, resulted negative with cultural methods (78\% of sensitivity). When cavitary fluids were directly analysed with FAT, only 3 cases resulted positive; DNA of 6 negative samples were subsequently extracted and analysed with FAT: 2 peritoneal fluids and 1 pleural fluid resulted positive. The remaining negative samples were negative also with cultural methods, except one peritoneal fluid that resulted $E$. coli positive with RT-PCR and cultural methods. Sensitivity of FAT was doubled when extracted DNA (67\%) instead of direct primary fluid analysis (33\%) was analysed.

\section{Discussion}

Despite the breakthrough in the diagnosis and treatment of infectious diseases, meningitis still remains an important cause of mortality and morbidity (5). An accurate and rapid diagnosis of acute bacterial meningitis is essential for a good outcome. To reduce death or permanent neurological sequelae as much as possible, a fast and correct diagnosis of bacterial meningitis is crucial. The gold standard test for acute bacterial/viral meningitis is CSF analysis (CPCE, GSS, CLAT, CCT). CPCE is a test performed in emergency regimen and it is considered the key test for the diagnosis of infectious (bacterial/viral) meningitis (54). However, literature reported conflicting data $(10,13,41,53,56,61)$. Data from our study confirm that CSF leukocyte count lacks specificity and sensitivity for the differential diagnosis of bacterial and viral meningitis. Indeed, only $25 \%$ ( $8 / 32$ patients) of bacterial meningitis showed more than 300 cells/ $\mu \mathrm{L}$, with a mortality rate of $50 \%$ (4 patients). CPCE parameters with CSF total cells less than $300 / \mu \mathrm{L}$ and increased number of PMNC, often associated with mild/moderate increase of protein level and mild/moderate reduction of glycorrhachia, didn't provide a correct diagnosis of the infectious agent leading to treatment optimization (11). Our data demonstrated that CSF samples with mild/moderate pleocytosis and PMNC predominance (10-300 cells/ $\mu \mathrm{L}, 70 \%$ PMNC) had a PPV (for bacterial meningitis) of $59 \%$ that decreased up to $6 \%$ when MNC are predominant (>70\%), while NPV (for bacterial meningitis) was near $90 \%$ in both cases (Table 3 ). However, a cut-off value of 300 cells/ $\mu \mathrm{L}$ and a PMNC predominance (70\%) showed the highest PPV (100\%) and $\mathrm{NPV} \geq 90 \%$, as previously observed in other studies $(2,11)$. CSF cell count is indicative of bacterial meningitis but, in case of mild/moderate pleocytosis (10-300 cells/ $\mathrm{LL}$ ), PPV is extremely low (38\%). Most of patients presenting community-acquired bacterial meningitis have CSF parameters suggestive of bacterial meningitis (61), however, cases, often children, without initial CSF findings are reported in the literature $(24,41,61)$. Our obser-

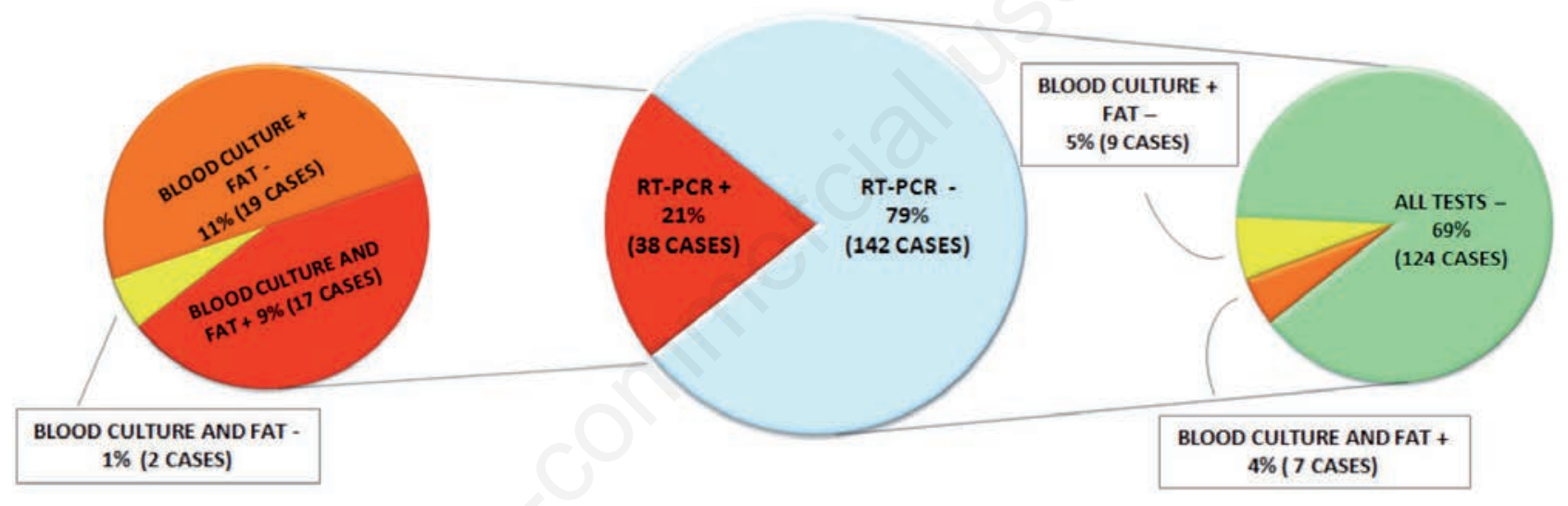

Figure 1. Results obtained from the analysis of 180 samples of peripheral blood by cultural methods, RT-PCR, and FilmArray Technology - Blood Culture Identification Panel (FAT-BCIP) performed directly on blood.

Table 5. Results obtained from analysis of 9 cavitary fluids by traditional cultural methods, RT-PCR, and FilmArray Technology - Blood Culture Identification Panel (FAT-BCIP), performed directly on cavitary fluids or extracted DNA.

\begin{tabular}{|c|c|c|c|c|}
\hline & Cultural methods & RT-PCR & FAT-BCIP (cavitary fluid) & FAT-BCIP (extracted DNA) \\
\hline \multicolumn{5}{|l|}{ Peritoneal fluids ( $\mathrm{n}=4$ ) } \\
\hline E. coli & 2 & 2 & 0 & 1 \\
\hline K. pneumoniae & 1 & 1 & 1 & 1 \\
\hline P. aeruginosa & 1 & 1 & 0 & 1 \\
\hline \multicolumn{5}{|l|}{ Pleural fluids $(n=4)$} \\
\hline S. pneumoniae & 1 & 2 & 1 & 1 \\
\hline K. pneumoniae (KPC) & 1 & 1 & 0 & 1 \\
\hline H. influenzae & 0 & 1 & 0 & 0 \\
\hline \multicolumn{5}{|l|}{ Synovial fluid (n=1) } \\
\hline S. aureus & 1 & 1 & 1 & 1 \\
\hline Positive samples & 7 & 9 & 3 & 6 \\
\hline Sensitivity & $77.78 \%$ & $100 \%$ & $33.33 \%$ & $66.67 \%$ \\
\hline
\end{tabular}


vations confirm these data, as shown by one patient infected with $S$. pneumoniae, having normal CSF cell counts, negative CCT and GSS but positive RT-PCR.

The emergency protocol for CSF analysis includes: CPCE, GSS, CCT, CLAT and BC, to perform before antibiotic therapy administration, when possible. Bacterial concentration in CSF is a limiting factor for microscopic results: positive results are only $25 \%$ with $<10^{3} \mathrm{CFU} / \mathrm{mL}$, $60 \%$ in the range of $10^{3}$ to $10^{5} \mathrm{CFU} / \mathrm{mL}$ and $98 \%$ with $>10^{6} \mathrm{CFU} / \mathrm{mL}$ $(51,65)$. Also CCT sensitivity is reported to be low: $61-66 \%$ when CSF collection is performed before starting therapy (5). When antimicrobial therapy was started before lumbar puncture, the sensitivity of CPCE and GSS in combination was lower than 50\% (13).

In the presence of a low number of viable organism in CSF, results of CCT could be made available only after 24-72 hrs or more. In our study bacterioscopic examination of GSS showed a reduced sensitivity (41\%), however it should be always performed in a routine regimen because of its rapidity, inexpensiveness and ability to find pathogens not detectable with RT-PCR.

A rapid test that can be performed in emergency regimen is CLAT, characterized by a reduced TAT (15 minutes) as compared to CCT. However, CLAT is considered out-dated because of its low sensitivity (0-35\%) (11). Even if it can be useful to detect not viable bacteria, to obtain a positive result (27) CLAT requires high concentrations of bacteria $\left(\geq 10^{6} \mathrm{CFU} / \mathrm{mL}\right)$. As recommended by several authors in the literature, CLAT should not be performed because, often, the moderate benefit of its use, in emergency regimen, contrasts with the risk of falsenegative results, which could wrongly reassure the clinician (29). Despite this criticism, CLAT is still performed as an emergency test, because of its easiness and rapidity (15 minutes).

Our data confirm that, overall, the sensitivity of traditional tests currently performed in emergency regimen (CPCE, CLAT, CCT, GSS) is lower than 50\%. Although, CCT remains the gold standard for antimicrobial susceptibility test, other technologies are necessary to improve the sensitivity of infectious meningitis diagnostic.

Since the 1990s, PCR-based assays has been available to provide an early and accurate diagnosis of bacterial meningitis $(23,35)$. Fluorescence-based PCR (such as RT-PCR) methods are now available, not only to detect viral DNA/RNA, but also for bacteria $(1,18,19,47,59,60)$. These methods are rapid, specific and sensitive; they are performed in closed-tube format, reducing the risk of contamination at all stages. In addition, post-PCR procedures (such as gel electrophoresis) are eliminated and results are interpreted by integrated fluorometry. RT-PCR has been shown to detect up to $10^{2}-10^{4} \mathrm{CFU} / \mathrm{mL}$, calculated on negative CSF spiked with scalar concentrations of bacterial strains $(59,60)$ and to be more sensitive and specific than CLAT, CCT and GSS $(6,39,60)$. Moreover, RT-PCR has the advantage that DNA/RNA extraction, liquid handling, PCR and analysis can be fully automated, allowing its use also in emergency regimen. For bacterial meningitis diagnosis, our data showed that RT-PCR has sensitivity and NPV of $100 \%$, as previously observed $(1,19,47,59)$ and confirm RT-PCR as the most sensitive method to detect bacterial DNA in meningitis cases. RT-PCR was able to detected those pathogens shown in Table 2 in $13 \%$ of analysed CSF (32/240), while CCT and BC detected them only in $5 \%(13 / 240)$ and $6 \%(15 / 240)$ of the samples, respectively, although microorganisms were completely concordant. With RT-PCR, detection rate for $S$. pneumoniae in CSF was high (4.6\% of analyzed CSF, 11 cases) followed by $L$. monocytogenes (3\%, 7 cases). In our population $S$. pneumoniae was confirmed as the main aetiological agent for bacterial meningitis, according to epidemiological worldwide studies $(11,28)$. CCT sensitivity for $S$. pneumoniae was only $45 \%$, but some authors observed a CCT sensitivity for this pathogen even lower (18.2\%)(4).

Another significant advantage of RT-PCR tests is the reduced TAT compared to CCT (3 vs 24-72 hrs). RT-PCR technology could be important also to quantify bacterial load, suggested as a prognostic marker in several studies $(17,26,45)$. This observation is also confirmed by our data showing that patients with high pneumococcal load ( $\mathrm{Ct} \leq 15 ; \mathrm{n}=2)$ and $L$. monocytogenes load $(\mathrm{Ct}=13 ; \mathrm{n}=1)$ had an adverse outcome. In these three cases CPCE showed values of PPV $>90 \%$, as previously reported by Spanos et al.(53) In spite of its higher sensitivity and specificity, RT-PCR requires trained personnel and non-negligible operator time (about 30 minutes) for laboratories that do not have a fully automated molecular platform. These aspects led to the implementation of molecular Point Of Care Tests (POCT) easily performable even for untrained personnel and with an extremely reduced TAT (up to $1 \mathrm{hr}$ ). These rapid tests (FilmArray, Biofire; Verigene, Nanosphere) have been first developed for sepsis management and have been validated on positive $\mathrm{BC}(3,8,12,43,55,57)$. Few data are available in the literature about an off-label application of these technologies on primary samples (CSF/blood) (40). Our study is focused on clinical validation of FAT, analysing directly CSF or blood samples without pre-treatment (off-label use), and on its application in an optimized diagnostic algorithm for meningitis management. We compared results obtained performing FAT directly on CSF with the other methods used for meningitis diagnosis in our laboratory. FAT is a rapid test (TAT=1 hr), with an operator time of $2 \mathrm{~min}$ and a fully automated results interpretation. This method, CE/IVD labelled exclusively on positive BC, was previously validated on CSF with negative CSF spiked with scalar concentrations of standard ATCC/NCTC bacterial strains (39) and it showed an analytical sensitivity about 100 times lower than RT-PCR. Clinical sensitivity of FAT measured in this study (62.5\%) was higher as compared with the other methods currently performed in emergency regimen for meningitis diagnosis, demonstrating that FAT is an effective method for emergency meningitis management, especially considering reduced TAT, easy execution and elevated automation.

The choice of the molecular method depends on the laboratory organization for emergency management, such as the degree of integration with routine diagnostic, depending on available resources and on the on-call service of the microbiologist or other specialized personnel. Figure 2 shows the diagnostic algorithm that we suggest for suspected bacterial/viral meningitis diagnosis, based on results obtained. Briefly, FAT should replace CLAT and GSS performed in emergency regimen (if they are still executed) because it is more sensitive, rapid and with an easier and objective interpretation. When CPCE does not show alterations, FAT should be performed when requested by the clinician and in case of a strong suspicion of bacterial meningitis, in agreement with observations, reported in literature, of bacterial meningitis cases without any cells detected at CPCE. Positive FAT results should be confirmed with RT-PCR, using the bacterial panel but not the viral panel, in rapid routine regimen (by 12 noon on the first working day), to quantify the bacterial load, important for patient's prognosis and follow-up. If CPCE is suggestive of infectious meningitis but FAT results are negative, RT-PCR should be performed as a more sensitive method to detect bacterial DNA and, only under clinical indication, to detect viral DNA/RNA.

Molecular methods performed to detect bacterial, viral and fungal nucleic acids for meningitis diagnosis are also applied in sepsis management, another important microbiological emergency $(9,15,36,37,50) . \mathrm{BC}$ is still considered the gold standard for diagnosis and identification of bloodstream pathogens (36), but long TAT (24-72 hrs for positive results and up to 5 days for negative results) and low sensitivity (estimated around 20-40\%) (50) don't allow the immediate beginning of a targeted therapy to reduce mortality (22) and management costs (31). These limitations led to the implementation of rapid and sensitive diagnostic methods for sepsis management. Molecular methods performed directly on blood have not shown the same diagnostic impact observed on meningitis, for several reasons.

Firstly, most methods can detect only few pathogens. As for meningitis, implementation of molecular tests based on broad-range PCR pres- 
ents technical problems such as high risk of contamination and variable extractive yield. For sepsis diagnosis, the most widely used molecular test is the LighCycler SeptiFast (Roche), CE/IVD approved. It is a multiplex RT-PCR that identifies 25 pathogens, responsible for $90 \%$ of sepsis, amplifying a portion of rRNA genes; the identification is performed by melting curve analysis (15). Compared to BC, SeptiFast has shown high specificity (92\%) but variable sensitivity, with an average of $75 \%$ (15), even if higher than BC (36).

Secondly, DNA extraction protocols with the same efficiency for Gram positive and Gram negative bacteria are not yet available. Most studies use enzymatic treatment (proteinase $\mathrm{K}$ or lysozime), boiling, phenol-chloroform extraction, ethanol precipitation, commercial kits or some combination of these methods (19). However, chemical extraction procedures that use phenol and chloroform are dangerous for laboratory personnel because of the toxic nature of both compounds. Since 1990 s, physical disruption in combination with the use of a commercial extraction kit has been demonstrated to have the same quality as standard phenol-chloroform extraction (46). Recently, several screening assays have been developed to detect bacterial and fungal DNA $(7,49)$. Complete automation of extraction, set-up, amplification and detection phases and Next Generation Sequencing technology development will lead to the availability of commercial diagnostic kit for screening and typing pathogens, that are not yet in use for routine regimen (33). Currently, many of the developed molecular tests (FISH, PCR, microarray, mass spectrometry) are focused on rapid pathogen identification not directly on blood, but on positive BC (TAT $\geq 24 \mathrm{hrs)}(36,37)$.

In our study molecular methods were performed on positive BC and directly on blood (off-label application for FAT) and cavitary fluids. We compared sensitivity, NPV and TAT among BC, the gold standard for diagnosis and identification of bloodstream pathogens (36), RT-PCR and FAT.

For sepsis diagnosis, our data confirm BC as the most sensitive test $(96 \%)$ with the limitation of an elevated TAT, as described elsewhere $(9,50)$. RT-PCR showed reduced TAT (2-3 hrs) and high sensitivity for detectable pathogens (95\%), but low overall sensitivity (70\%). FAT performed directly on positive BC has reduced TAT (1 hr vs $12 \mathrm{hrs)} \mathrm{com-}$ pared to biochemical identification with Vitek 2 System and even to MALDI-TOF (6-8 hrs) (32). With these methods TAT is high because identification depends on pathogen's growth in BC. FAT performed directly on blood has short TAT (1 hr) compared to BC but low clinical sensitivity (44\%), probably due to its lower analytical sensitivity compared to RT-PCR (100 times lower), as described in CSF with standard ATCC/NCTC bacterial strains (39).

\section{DIAGNOSTICPATHWAY IN SUSPECTED BACTERIAL/VIRALMENINGITIS}

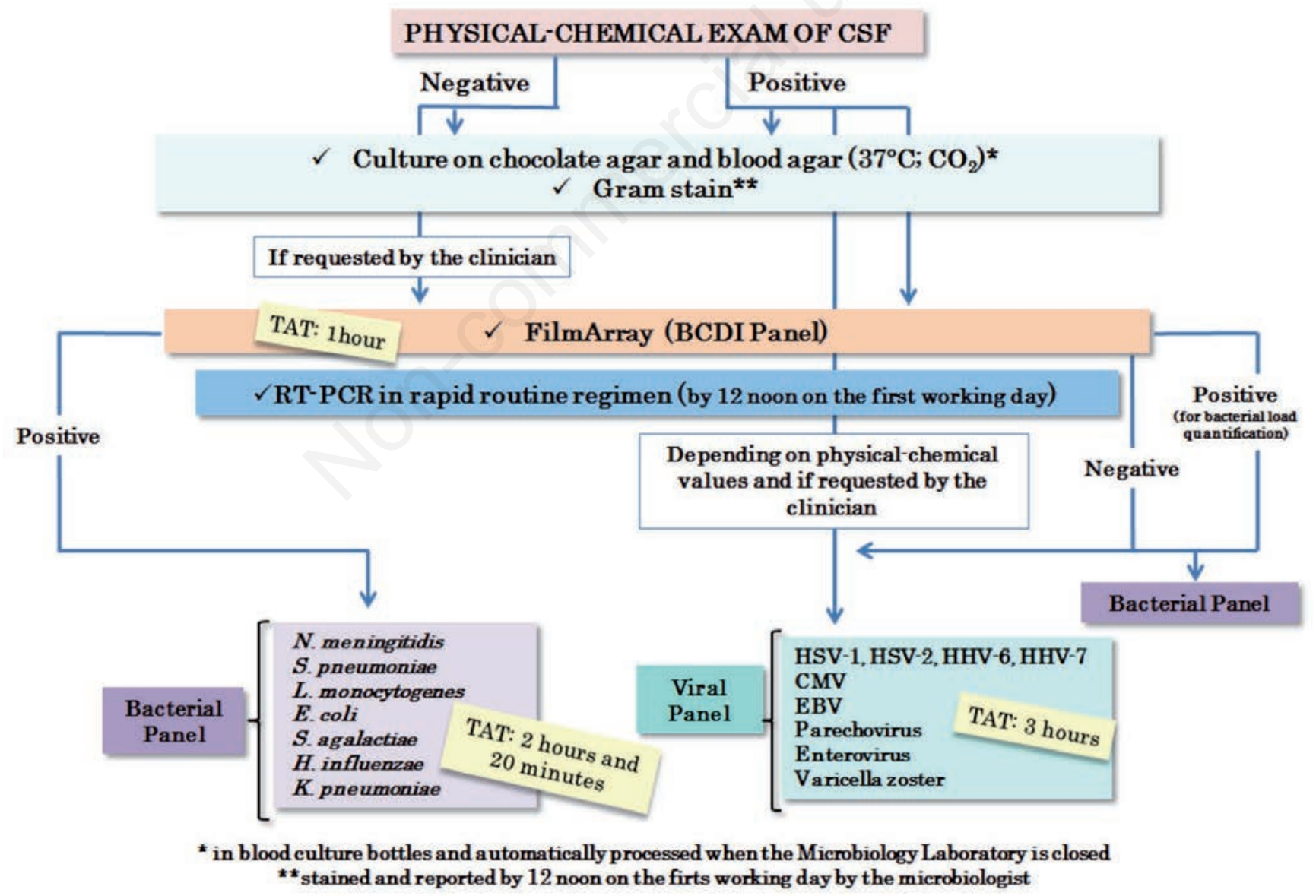

TAT, Turn Around Time; BCDI, Blood Culture Identification Panel; HSV, Herpes Simplex Virus; HHV, Human Herpes Virus; CMV, Citomegalovirus; EBV, Epstein-Barr Virus.

Figure 2. Diagnostic algorithm proposed for suspected bacterial/viral meningitis diagnosis. 
RT-PCR is extremely flexible and applicable to all biological matrices, proved to be a sensitive and specific test to detect severe infections directly from biological fluids as pleural, peritoneal and synovial fluids (Table 5). Preliminary data from our study show a sensitivity of $100 \%$, $78 \%$ and $67 \%$ for RT-PCR, cultural methods and FAT, respectively. The reduced sensitivity of FAT is attributable to its low extractive yield, when performed on complex matrices. In fact, when FAT is performed on extracted DNA, its sensitivity is doubled (33\% vs 67\%). However, in case of severe sepsis, performing FAT, even if expensive, is widely justified by the rapid diagnosis, also considering that its sensitivity is not much lower as compared to cultural methods, requiring long TAT for pathogen identification. RT-PCR and FAT, used for sepsis diagnosis, should be implemented by increasing the number of detectable pathogens (RTPCR) and improving extractive yield and analytical sensitivity (FAT).

\section{Conclusions}

Our study confirmed the central role of molecular methods in meningitis and sepsis management. RT-PCR showed the highest sensitivity and NPV in meningitis diagnosis, while FAT, with a higher sensitivity and rapidity and an easier and objective interpretation, should replace CLAT and GSS in emergency regimen. Both methods showed a reduced TAT compared to conventional methods. RT-PCR can be performed on all biological matrices with a limited number of detectable pathogens influencing its sensitivity; FAT resulted easy to perform and in result interpretation, even if we reported a suboptimal performance when primary matrices are analysed; however, in cases of severe sepsis, RT-PCR and FAT use is effective and appropriated.

\section{Acknowledgments}

We are grateful to Laura Della Corte for critical reading of the manuscript and to Margherita Niccolai for her support in the study. We acknowledge DID Diagnostic International Distribution S.p.A. for providing equipment and reagents for the FilmArray assay.

\section{References}

1. Abdeldaim GMK, Stralin K, Korsgaard S, et al. Multiplex quantitative PCR detection of lower respiratory tract infection and meningitis caused by Streptococcus pneumoniae, Haemophilus influenzae and Neisseria meningitidis. BMC Microbiol 2010; 10: 310-9.

2. Agueda S, Campos T, Maia A. Prediction of bacterial meningitis based on cerebrospinal fluid pleocytosis in children. Braz J Infect Dis 2013; 17: 401-4.

3. Altun 0, Almuhayawi M, Ullberg M, Ozenci V. Clinical evaluation of the FilmArray BC identification panel in identification of bacteria and yeasts from positive BC bottles. J Clin Microbiol 2013; 51: 4130-6.

4. Azzari C, Moriondo M, Indolfi G, et al. Molecular detection methods and serotyping performed directly on clinical samples improve diagnostic sensitivity and reveal increased incidence of invasive by Streptococcus pneumoniae in Italian children. J Med Microbiol 2008; 57: 1205-12.

5. Bamberger DM. Diagnosis, initial management, and prevention of meningitis. Am Fam Physician 2010; 82: 1491-8.

6. Bianchi L, Niccolai M, Lencioni P, Lari R. Diagnosis of infections of the central nervous system: when, why and how to use new technologies in the management of the examination of cerebralspinal fluid (CSF) in emergency. Clin Chem and Lab Med 2010; 48: A128.
7. Bispo PJM, de Melo GB, Hofling-Lima AL, Campos Pignatari AC. Detection and Gram discrimination of bacterial pathogens from aqueous and vitreous humor using Real-Time PCR assays. Invest Ophthalmol Vis Sci 2011; 51: 873-81.

8. Blaschke AJ, Heyrend C, Byington CL, et al. Rapid identification of pathogens from positive BCs by multiplex PCR using the FilmArray System. Diagn Microbiol Infect Dis 2012; 74: 349-55.

9. Bloos F, Reinhart K. Rapid diagnosis of sepsis. Virulence 2014; 5 : 154-60.

10. Bonsu BK, Harper MB. Differentiating acute bacterial meningitis from acute viral meningitis among children with cerebrospinal fluid pleocytosis: a multivariable regression model. Pediatr Infect Dis J 2004; 23: 511-7.

11. Brouwer MC, Tunkel AR, Van de Beek D. Epidemiology, diagnosis and antimicrobial treatment of acute bacterial meningitis. Clin Microbiol Rev 2010; 23: 467-92.

12. Buchan BW, Ginocchio CC, Manii R, et al. Multiplex identification of Gram-positive bacteria and resistance determinants directly from positive BC broths: evaluation of an automated microarraybased nucleic acid test. PLoS Med 2013; 10: e1001478.

13. Carbonnelle E. Laboratory diagnosis of bacterial meningitis: usefulness of various tests for the determination of the etiological agent. Med Mal Infect 2009; 39: 581-605.

14. Ceyhan M, Yildirim I, Balmer P, et al. A prospective study of etiology of childhood acute bacterial meningitis, Turkey. Emerg Infect Dis 2008; 14: 1089-96.

15. Chang S, Hsieh W, Liu T, et al. Multiplex PCR system for rapid detection of pathogens in patients with presumed sepsis - a systemic review and meta-analysis. PLoS One 2013; 8: e62323.

16. Chiba N, Murayama SY, Morozumi M, et al. Rapid detection of eight causative pathogens for the diagnosis of bacterial meningitis by realtime PCR. J Infect Chemother 2009; 15: 92-8.

17. Chuang $\mathrm{H}$, Chang $\mathrm{S}$, Wang $\mathrm{W}$. High and increasing 0xa-51 DNA load predict mortality in Acinetobacter baumannii bacteremia: implication for pathogenesis and evaluation of therapy. PLoS One 2010; 5: e14133.

18. Clarke SC. Detection of Neisseria meningitidis, Streptococcus pneumoniae and Haemophilus influenzae in blood and cerebrospinal fluid using fluorescence-based PCR. Methods Mol Biol 2006; 345: 69-77.

19. Corless CE, Guiver M, Borrow R, et al. Simultaneous detection of Neisseria meningitidis, Haemophilus influenzae, and Streptococcus pneumoniae in suspected cases of meningitis and septicemia using Real-Time PCR. J Clin Microbiol 2001; 39: 1553-8.

20. Croxatto A, Prodhom G, Greud G. Applications of MALDI-TOF mass spectrometry in clinical diagnostic microbiology. FEMS Microbiol Rev 2012; 36: 380-407.

21. Dubos F, Korczowski B, Aygun DA, et al. Serum procalcitonin level and other biological markers to distinguish between bacterial and aseptic meningitis in children: a European multicenter case cohort study. Arch Pediatr Adolesc Med 2008; 162: 1157-63.

22. Gaieski DF, Pines JM, Band RA, et al. Impact of time to antibiotics on survival in patients with severe sepsis or septic shock in whom early goal-directed therapy was initiated in the emergency department. Crit Care Med 2010; 38: 1-9.

23. Greisen K, Loeffelholz M, Purohit A, Leong D. PCR primers and probes for the $16 \mathrm{~S}$ rRNA gene of most species of pathogenic bacteria, including bacteria found in cerebrospinal fluid. J Clin Microbiol 1994; 32: 335-51.

24. Hase R, Hosokawa N, Yaegashi M, Muranaka K. Bacterial meningitis in the absence of cerebrospinal fluid pleocytosis: a case report and review of the literature. Can J Infect Dis Med Microbial 2014; 25: 249-51.

25. Heininger A, Binder M, Ellinger A, et al. Effect of comprehensive validation of the template isolation procedure on the reliability of bacteraemia detection by a $16 \mathrm{~S}$ rRNA gene PCR. Clin Microbiol Infect 2004; 10: 452-8. 
26. Ho Y, Chang S, Lin S, Wang W. High levels of mecA DNA detected by a quantitative Real-Time PCR assay are associated with mortality in patients with methicillin-resistant Staphylococcus aureus bacteremia. J Clin Microbiol 2009; 47: 1443-51.

27. Holloway Y, Boersma WG, Kuttschrütter H, Snijder JA. Minimun number of pneumococci required for capsular antigen to be detected by latex agglutination. J Clin Microbiol 1992; 30: 517-9.

28. Italian National Institute of Health, Roma. Dati di sorveglianza delle malattie batteriche invasive aggiornati al 31 ottobre 2014. Available from: http://www.iss.it/mabi

29. Karre T, Mandrekar JN, Patel R. Comparison of bacterial antigen test and Gram Stain for detecting classic meningitis bacteria in cerebrospinal fluid. J Clin Microbiol 2010; 48: 1504-5.

30. Kennedy W, Chang SJ, Purdy K, et al. Incidence of bacterial meningitis in Asia using enhanced CSF testing: polymerase chain reaction, latex agglutination and culture. Epidemiol Infect 2007; 135: 1217-26.

31. Koenig A, Picon AD, Feijó J, et al. Estimate of the economic impact of implementing an in hospital protocol for the early detection and treatment of severe sepsis in public and private hospitals in southern Brazil. Rev Bras Ter Intensiva 2010; 22: 213-9.

32. Kok J, Thomas LC, Olma T, et al. Identification of bacteria in BC broths using Matrix-Assisted Laser Desorption-Ionization Sepsityper ${ }^{\mathrm{TM}}$ and Time of Flight Mass Spectrometry. PLoS One 2011; 6: e23285.

33. Koser CU, Holden MTG, Ellington MJ, et al. Rapid whole-genome sequencing for investigation of a neonatal MRSA outbreak. N Engl J Med 2012; 366: 2267-75.

34. Køster-Rasmussen R, Korshin A, Meyer CN. Antibiotic treatment delay and outcome in acute bacterial meningitis. J Infect 2008; 57: 449-54.

35. Kotilainen P, Jalava J, Meurman 0, et al. Diagnosis of meningococcal meningitis by broad-range bacterial PCR with cerebrospinal fluid. J Clin Microbiol 1998; 36: 2205-9.

36. Liesenfeld 0, Lehman L, Hunfeld KP, Kost G. Molecular diagnosis of sepsis: new aspects and recent developments. Eur J Microbiol Immunol 2014; 4: 1-25.

37. Mancini N, Carletti S, Ghidoli N, et al. The era of molecular and other non-culture-based methods in diagnosis of sepsis. Clin Microbiol Rev 2010: 23: 235-51.

38. Meyer T, Franke G, Polywka SKA, et al. Improved detection of bacterial central nervous system infections by use of a broad-range PCR assay. J Clin Microbiol 2014; 52: 1751-3.

39. Napoli Z, Donati M, Cafissi A, et al. Valutazione di sensibilità e specificità delle metodiche Filmarray e RT-PCR mediante impiego di ceppi di riferimento NCTC e ATCC. Biochim Clin 2014; 38: 465.

40. Pardo J, Klinker KP, Borgert SJ, et al. Detection of Neisseria meningitidis from negative BCs and cerebrospinal fluid with the FilmArray BC identification panel. J Clin Microbiol 2014; 52: 2262-4.

41. Polk DB, Steele RW. Bacterial meningitis presenting with normal cerebrospinal fluid. Pediatr Infect Dis J 1987; 6: 1040-2.

42. Proulx N, Fréchette D, Toye B, et al. Delays in the administration of antibiotics are associated with mortality from adult acute bacterial meningitis. QJM 2005; 98: 291-8.

43. Rand KH, Delano JP. Direct identification of bacteria in positive BCs: comparison of two rapid methods, FilmArray and mass spectrometry. Diagn Microbiol Infect Dis 2014; 79: 293-7.

44. Regueiro BJ, Varela-Ledo E, Martinez-Lamas L, et al. Automated extraction improves multiplex molecular detection of infection in septic patients. PLoS One, 2010; 5: 1-8.

45. Rello J, Lisboa T, Lujan M, et al. Severity of pneumococcal pneumonia associated with genomic bacterial load. Chest 2009; 136: 832-40.

46. Rochelle PA, Weightman AJ, Fry JC. DNase I treatment of TaqDNA polymerase for complete PCR decontamination. BioTechniques 1992; 13: 520.

47. Sacchi CT, Fukasawa LO, Goncalves MG, et al. Incorporation of RealTime PCR into routine public health surveillance of culture negative bacterial meningitis in São Paulo, Brazil. Plos One 2010; 6: e20675.

48. Saravolatz LD, Manzor 0, VanderVelde N, et al. Broad-range bacte- rial polymerase chain reaction for early detection of bacterial meningitis. Clin Infect Dis 2003; 36: 40-5.

49. Schabereiter-Gurtner C, Selitsch B, Rotter ML, et al. Development of novel Real-Time PCR assays for detection and differentiation of eleven medically important Aspergillus and Candida species in clinical specimens. J Clin Microbiol 2007; 45: 906-14.

50. Schaub N, Boldanova T, Noveanu M, et al. Incremental value of multiplex real-time PCR for the early diagnosis of sepsis in the emergency department. Swiss Med Wkly 2014; 144: w13911.

51. Schuurman T, de Boer RF, Kooistra-Smid AMD, van Zwet AA. Prospective study of use of PCR amplification and sequencing of $16 \mathrm{~S}$ ribosomal DNA from cerebrospinal fluid for diagnosis of bacterial meningitis in a clinical setting. J Clin Microbiol 2004; 42: 734-40.

52. Simon TD, Yserloo BV, Nelson K, et al. Use of quantitative $16 \mathrm{~S}$ rRNA PCR to determine bacterial load does not augment conventional cerebrospinal fluid (CSF) cultures among children undergoing treatment for CSF shunt infection. Diagn Microbiol Infect Dis 2014; 78: 188-95.

53. Spanos A, Harrel FE Jr, Durack DT. Differential diagnosis of acute meningitis. An analysis of the predictive value of initial obsevations. JAMA 1989; 262: 2700-7.

54. Straus SE, Thorpe KE, Holroyd-Leduc J. How do I perform a lumbar puncture and analyze the results to diagnose bacterial meningitis? JAMA 2006; 296: 2012-22.

55. Sullivan KV, Turner NN, Roundtree SS, et al. Rapid detection of Gram-positive organisms by use of the Verigene Gram-positive BC nucleic acid test and the BacT/Alert pediatric FAN System in a multicenter pediatric evaluation. J Clin Microbiol 2013; 51: 3579-84.

56. Suzuki H, Tokuda Y, Kurihara Y, et al. Adult pneumococcal meningitis presenting with normocellular cerebrospinal fluid: two case reports. J Med Case Rep 2013; 7: 294.

57. Tojo M, Fujita T, Ainoda Y, et al. Evaluation of an automated rapid diagnostic assay for detection of Gram-negative bacteria and their drug-resistance genes in positive BCs. PLoS One 2014; 9: e94064.

58. Tunkel AR, Hartman BJ, Kaplan SL, et al. Practice guidelines for the man-agement of bacterial meningitis. Clin Infect Dis 2004; 39 : 1267-84.

59. Wang X, Theodore MJ, Mair R, et al. Clinical validation of multiplex Real-Time PCR assays for detection of bacterial meningitis pathogens. J Clin Microbiol 2012; 50: 702-8.

60. Wang Y, Guo G, Wang H, et al. Comparative study of bacteriological culture and real-time fluorescence quantitative PCR (RT-PCR) and multiplex PCR-based reverse line blot (mPCR/RLB) hybridization assay in the diagnosis of bacterial neonatal meningitis. BMC Pediatr 2014; 14: 224.

61. Weisfelt M, van de Beek D, Spanjaard L, et al. Attenuated cerebrospinal fluid leukocyte count and sepsis in adults with pneumococcal meningitis: a prospective cohort study. BMC Infect Dis 2006; 6: 149.

62. Werno AM, Anderson TP, Murdoch DR. Association between pneumococcal load and disease severity in adults with pneumonia. J Med Microbiol 2012; 61: 1129-35.

63. Won H, Yanga S, Gaydosa C, et al. A broad range assay for rapid detection and etiologic characterization of bacterial meningitis: performance testing in samples from sub-Sahara. Diagn Microbiol Infect Dis 2012; 74: 22-7.

64. World Health Organization and Centers for Disease Control and Prevention. Laboratory methods for the diagnosis of meningitis caused by Neisseria meningitidis, Streptococcus pneumoniae, and Haemophilus influenzae. Second edition (2011). Available from: http:/www.cdc.gov/meningitis/lab-manual

65. Wu HM, Cordeiro SM, Harcourt BH, et al. Accuracy of real-time PCR, Gram stain and culture for Streptococcus pneumoniae, Neisseria meningitidis and Haemophilus influenzae meningitis diagnosis. BMC Infect Dis 2013; 13: 26.

66. Yahia MA, Balach 0. Comparison of multiplex PCR, Gram stain, and culture for diagnosis of acute bacterial meningitis. Int J Pharm Pharm Sci 2014; 6: 425-9. 